\title{
THE DIFFERENCE BETWEEN LEFT AND RIGHT COLON CANCER PATIENTS' CHARACTERISTICS - SINGLE CENTER EXPERIENCE
}

\author{
DARKO KOTROMANOVIĆ ${ }^{,}$, ZDENKA KOTROMANOVIĆ ${ }^{2}$, ILIJAN TOMAŠ ${ }^{1}$, JOSIPA FLAM ${ }^{1}$, \\ SONJA KOTROMANOVIĆ ${ }^{3}$, ŽELJKO KOTROMANOVIĆ ${ }^{4}$ and MIRELA PENC ŠAMBIĆ ${ }^{2}$ \\ ${ }^{1}$ Department of Otorhinolaryngology and Plastic Surgery of the Head and Neck, \\ University Hospital Center Osijek, Osijek, Croatia; \\ ${ }^{2}$ Institute of Oncology, University Hospital Center Osijek, Osijek, Croatia; \\ ${ }^{3}$ Department of Anesthesiology, Reanimatology and Intensive Care, University Hospital Dubrava, \\ Zagreb, Croatia; \\ ${ }^{4}$ School of Medicine, Osijek, Croatia
}

\section{Summary}

Objectives: The purpose of the study was to determine the difference in time until the appearance of relapse or metastases in patients treated for colorectal cancer, depending on the location of the tumor in the left or right colon at the Oncology Clinic of Clinical Medical Centre Osijek between 1 January 2010 and 31 $1^{\text {st }}$ December 2012.

Study design: historical prospective study

Material and methods: Study included patients whose data were recorded from medical archive at the Oncology Clinic of Clinical Medical Centre Osijek. The data on patients' deaths were recorded from the Registry Office of the Republic of Croatia.

Results: The study included 272 patients, 160 (58.8\%) men and 112 (41.2\%) women. According to the location, left sided colon tumor was discovered in 211 (77.6\%) patients and right-sided in 61 (22.4\%). The median age was 67 years. Right-sided colon tumors are considerably larger with median diameter of $6 \mathrm{~cm}$, with median number of 16 . Median of time until the appearance of the metastases is 20 months (interquartile range is from 8 to 29 months); marked time being shorter in right-sided colon tumors. Positive outcome of the treatment was achieved in $205(75.4 \%)$ patients, with no significant difference in comparison to the colon cancer localization. By using Kaplan-Meier analysis of patients' survival rates, a total 5- year survival rate of $72 \%$ was achieved in right-sided colon tumor in comparison to $62 \%$ in patients with the left-sided colon tumor.

Conclusion: This study confirms that there is a difference in colorectal cancer according to its localisation. Patients with right-sided colorectal cancer are older, the carcinoma is larger, the time until the appearance of a relapse or a metastases is shorter in right sided colon cancer while 5-year survival rate is lower in left sided colon cancer.

KEYWORDS: colorectal cancer, oncology, colon

\section{RAZLIKA IZMEĐU KARAKTERISTIKA BOLESNIKA S KARCINOMOM LIJEVOG I DESNOG KOLONA - ISKUSTVO JEDNE USTANOVE}

\section{Sažetak}

Cilj Istraživanja: Utvrditi razliku u vremenu do pojave recidiva ili presadnica kod bolesnika liječenih zbog kolorektalnog karcinoma ovisno o smještaju u lijevom ili desnom kolonu u pacijenata liječenih na Zavodu za onkologiju, KBC-a Osijek od 1. siječnja 2010. do 31. prosinca 2012. 


\section{Nacrt studije: Povijesno prospektivna studija}

Materijal i metode: U istraživanje su uključeni ispitanici čiji su podatci preuzeti iz arhive medicinske dokumentacije Zavoda za onkologiju KBC-a Osijek, podatci o smrti pacijenata preuzeti su od nadležnog Maticnog ureda Republike Hrvatske.

Rezultati: U istraživanje je uključeno 272 pacijenta, od kojih je 160 (58,8 \%) muškaraca i 112 (41,2 \%) žena. Prema lokalizaciji, ljevostrani tumor kolona ima 211 (77,6 \%) bolesnika, a desnostrani njih 61 (22,4 \%). Središnja dob pacijenta (medijan) je 67 godina. Značajno su veći u promjeru desni tumori kolona, medijana $6 \mathrm{~cm}$. Medijan vremena do pojave metastaza iznosi 20 mjeseci (interkvartilnog raspona 8 do 29 mjeseci), pri čemu je značajnije kraći kod desnih tumora kolona. Pozitivan ishod liječenja imalo je 205 (75,4 \%) bolesnika, bez značajne razlike u odnosu na lokalizaciju tumora kolona. Kaplan - Meierovom analizom preživljenja promatranih bolesnika podijeljenih prema lokalizaciji, dobiveno je petogodišnje ukupno preživljenje 72 \% za tumor u desnom kolonu, u odnosu na 62 \% kod bolesnika koji su imali tumor u lijevom kolonu.

Zaključak: U ovom istraživanju potvrđeno je da postoji razlika u kolorektalnom karcinomu s obzirom na njegov položaj. Pacijenti s desnim kolorektalnim karcinomom su starije dobi, tumor je veći u promjeru,vrijeme do pojave presadnica ili recidiva je kraće, te je petogodišnje preživljavanje manje.

Ključne rijeci: kolorektalni karcinom, onkologija, kolon

\section{INTRODUCTION}

Colorectal cancer is the third most frequent malignant tumor in the world. The newer studies indicate that tumors behave differently, depending on their position - left or right. An historical prospective study has been carried out in which various parameters were examined. These are the parameters of the carcinoma itself and its behaviour in the left or right colon, as well as the behaviour of left and right colon cancer according to difference in sex, TNM characteristics, time until the appearance of metastases or recidive, age limit and patients' survival rate $(1,2,6)$.

The colon was developed from the primitive gut. The development of the primitive gut and its derivatives is divided into four segments: esophagus, foregut, midgut and hindgut. The colon has different development because it was developed from the mid and hindgut. After the development ended, the midgut starts distally from the entry of gallibladder into the duodendum and it ends at the boundary between proximal $2 / 3$ and distal $1 / 3$ of the transverse colon, and through its whole lenght it is supplied by blood from $a$. mesenterica superior. From the hindgut develops distal $1 / 3$ of the colon, descending colon, sigmoid colon, rectum and the lower half of the anal canal (3).

The frequency of the carcinoma itself rises simultaneously with the industrial development of each country. The highest incidence rates are recorded in New Zealand, the USA, Canada and Great Britain, while low rates are registered in African countries, Asia and some parts of South
America. In the Republic of Croatia the incidence and mortality rates are similar to the median values in developed countries. In 2012 the incidence rate of colorectal cancer was 44,2/100000 in men, and $24,7 / 100000$ in women; the mortality rate in men was 26,7/100000, and in women 24,7/100000. Colorectal cancer is among ten most common causes of death in Osijek-Baranya county; it was ranked fourth with 158 deaths in $2016(1,4,5,10,11)$.

The cause of colorectal carcinoma itself, as well as of many other malignant diseases, remains unknown. However, it is known that certain factors can have an enormous influence on its development. Risk factors such as old age, nutrition rich in fat, but poor in fibres, contributes to the appearance of colorectal cancer. Genetic factors such as family adenomatose polyposis of the colon also add to its appearance $(1,2)$.

Hereditary predispositions, inflammatory intestine diseases, especially ulcerative colitis, as well as patiens who have already had a colorectal carcinoma and have undergone surgery, have a greater risk of developing this carcinoma $(1,2)$.

Pathological-anatomically speaking, most commonly it is an adenocarcinoma, localized in rectum and sigmoid colon, around $73 \%$, rarely in ascending colon, around $14 \%$. and in trensverse colon, around $10 \%$. According to gradus, we distinguish well differentiated, moderately differentiated and poorly differentiated. For clinical purposes the greatest influence has a pathohistological classification, which was introduced in 1930 by Dukes i Gordon-Watson $(1,2,7)$. 


\section{MATERIAL AND METHODS}

Study includes patients whose data were taken from medical archive at the Oncology Clinic of Clinical Medical Centre Osijek. The data on patients' deaths were taken from the Registry Office of the Republic of Croatia. 272 patients were involved from 2010 to 2012, including 2012

\section{RESULTS}

In the research 272 patients were involved from 2010 to 2012, including 2012, 160 (58,8 \%) men and 112 (41,2\%) women. According to tumor localization, left colon cancer had 211 (77,6\%) patients, and right colon cancer 61 patients $(22,4 \%)$. Table 1 is showing clinical-pathological and demographic data (Table 1.). In the research colon transversum was used as the border between left and right colon.

Table 1.

\section{LOCALIZATION OF COLON CANCER ACCORDING TO PATIENTS' GENDER AND AGE}

\begin{tabular}{|l|l|l|l|l|}
\hline \multicolumn{4}{|c|}{} & \multicolumn{3}{|l|}{$\begin{array}{l}\text { Number (\%) of patients according to } \\
\text { localization of colon cancer }\end{array}$} & \multirow{2}{*}{ P $^{*}$} \\
\cline { 2 - 4 } & $\begin{array}{l}\text { Right colon } \\
\text { cancer }\end{array}$ & $\begin{array}{l}\text { Left colon } \\
\text { cancer }\end{array}$ & Total & \\
\hline Gender & $35(57,4)$ & $125(59,2)$ & $160(58,8)$ & \multirow{2}{*}{0,88} \\
\hline Men & $26(42,6)$ & $86(40,8)$ & $112(41,2)$ & \\
\hline Women & $5(8,2)$ & $17(8,1)$ & $22(8,1)$ & \\
\cline { 1 - 4 } Patients' age & $7(11,5)$ & $57(27)$ & $64(23,5)$ & \\
\hline to 50 years & $22(36,1)$ & $57(27)$ & $79(29)$ & \\
\hline $51-60$ & $23(37,7)$ & $72(34,1)$ & $95(34,9)$ & \\
\hline $61-70$ & $4(6,6)$ & $8(3,8)$ & $12(4,4)$ & \\
\hline $71-80$ & $61(100)$ & $211(100)$ & $272(100)$ & \\
\hline $\begin{array}{l}51 \text { years } \\
\text { and older }\end{array}$ & & &
\end{tabular}

*Fisher's exact test

Median age was 67 years (interquartil range from $58-74$ years) at the range from 31 to 88 years. Most patients, 95 (34,9\%) were between 71 and 80 years old. Right colon cancer is significantly larger, median value $6 \mathrm{~cm}$ (interquartil range from 4,5 to $7 \mathrm{~cm}$ ) at the range from $2 \mathrm{~cm}$ to $13 \mathrm{~cm}$ (Mann Whitney $\mathrm{U}$ test, $\mathrm{P}=0,008)$, as well as the number of examined lymph nodes, median value 16 (interquartil range from 10 to 22) (Mann - Whitney U test, $\mathrm{P}<0,001)$. The number of infiltrated lymph nodes is not significantly different according to colon cancer localization (Table 2.)

The highest number of patients, 214 (78,7 \%), had T3 stage of the primary tumor, and in 157 $(57,7 \%)$ patients, regional lymph nodes not invaded. Lymphovascular invasion was not present in $221(81,3 \%)$ patients. There were no significant differences according to the colon cancer localization in terms of regional or local invasion (Table 3)

Table 2.

PATIENTS' AGE, THE SIZE OF CANCER AND THE NUMBER OF EXAMINED AND INVOLVED LYMPH NODES

\begin{tabular}{|l|l|l|l|l|}
\hline & \multicolumn{2}{|l|}{$\begin{array}{l}\text { Median (interquartil range) according } \\
\text { to colon cancer localization }\end{array}$} & \multirow{2}{*}{$\mathrm{P}^{*}$} \\
\cline { 2 - 4 } & $\begin{array}{l}\text { Right colon } \\
\text { cancer }\end{array}$ & $\begin{array}{l}\text { Left colon } \\
\text { cancer }\end{array}$ & Total & \\
\hline $\begin{array}{l}\text { Patients' age } \\
\text { (years) }\end{array}$ & $\begin{array}{l}70(62,5 \\
-75)\end{array}$ & $\begin{array}{l}66(57 \\
-74)\end{array}$ & $\begin{array}{l}67(58 \\
-74)\end{array}$ & 0,17 \\
\hline $\begin{array}{l}\text { The tumor size } \\
\text { (cm) }\end{array}$ & $6(4,5-7)$ & $5(4-6)$ & $5(4-6,5)$ & $\mathbf{0 , 0 0 8}$ \\
\hline $\begin{array}{l}\text { The number of } \\
\text { examined lymph } \\
\text { nodes }\end{array}$ & $\begin{array}{l}16(10 \\
-22)\end{array}$ & $10(7-16)$ & $\begin{array}{l}10,5(8 \\
-18)\end{array}$ & $\begin{array}{l}< \\
\mathbf{0}, 001\end{array}$ \\
\hline $\begin{array}{l}\text { The number of } \\
\text { involved lymph } \\
\text { nodes }\end{array}$ & $0(0-4)$ & $0(0-2)$ & $0(0-2)$ & 0,31 \\
\hline
\end{tabular}

*Mann - Whitney U test

Table 3.

T I N STAGE AND THE LYMPHOVASCULAR INVASION ACCORDING TO COLON CANCER LOCALIZATION

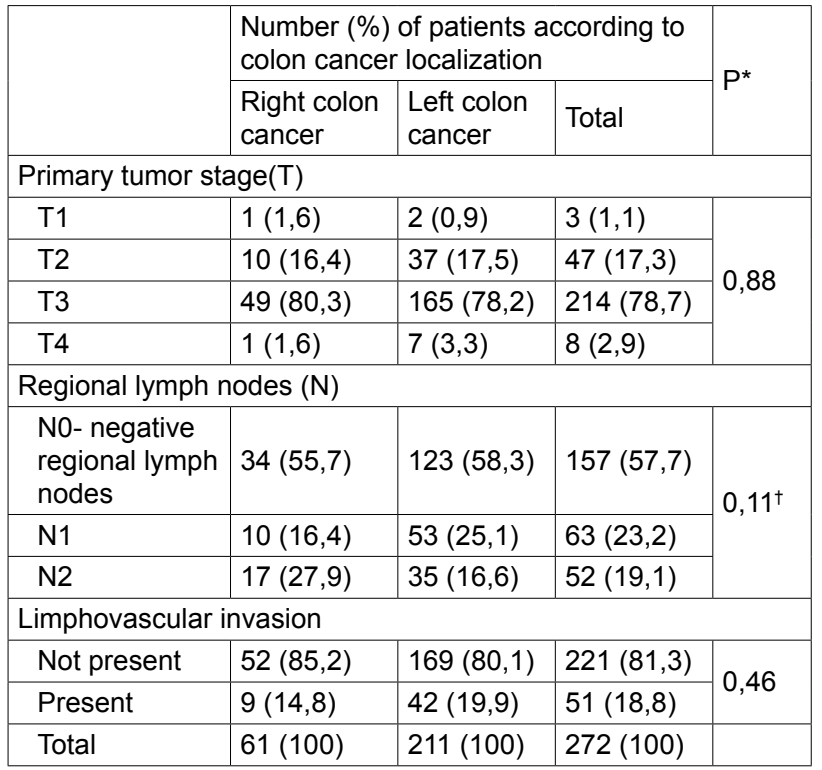

${ }^{*}$ Fisher's exact test; ${ }^{\dagger} \chi^{2}$ test 
Table 4.

THE EXISTENCE AND LOCALIZATION OF METASTASES ACCORDING TO COLON CANCER LOCALIZATION

\begin{tabular}{|c|c|c|c|c|}
\hline & \multicolumn{3}{|c|}{$\begin{array}{l}\text { Number (\%) of patients according to } \\
\text { localization of colon cancer }\end{array}$} & \multirow{2}{*}{$P^{*}$} \\
\hline & $\begin{array}{l}\text { Right colon } \\
\text { cancer }\end{array}$ & $\begin{array}{l}\text { Left colon } \\
\text { cancer }\end{array}$ & Total & \\
\hline \multicolumn{5}{|c|}{ Existence of metastases } \\
\hline Yes & $7(11,5)$ & $20(9,5)$ & $27(9,9)$ & \multirow{2}{*}{0,63} \\
\hline No & $54(88,5)$ & $191(90,5)$ & $245(90,1)$ & \\
\hline Total & $61(100)$ & $211(100)$ & $272(100)$ & \\
\hline \multicolumn{5}{|c|}{ Localization of metastases } \\
\hline Liver & $5 / 7$ & $13 / 19$ & $18 / 26$ & \multirow{5}{*}{0,92} \\
\hline Lungs & 0 & $2 / 19$ & $2 / 26$ & \\
\hline Peritoneus & 0 & $1 / 19$ & $1 / 26$ & \\
\hline Other & $1 / 7$ & $2 / 19$ & $3 / 26$ & \\
\hline Liver and lungs & $1 / 7$ & $1 / 19$ & $2 / 26$ & \\
\hline Total & $7 / 7$ & $19 / 19$ & $26 / 26$ & \\
\hline
\end{tabular}

*Fisher's exact test

Table 5.

TUMOR STAGE AND GRADUS ACCORDING TO THE COLON CANCER LOCALIZATION

\begin{tabular}{|c|c|c|c|c|}
\hline & \multicolumn{3}{|c|}{$\begin{array}{l}\text { Number }(\%) \text { of patients according to } \\
\text { the colon cancer localization }\end{array}$} & \multirow{2}{*}{$P^{*}$} \\
\hline & $\begin{array}{l}\text { Right colon } \\
\text { cancer }\end{array}$ & $\begin{array}{l}\text { Left colon } \\
\text { cancer }\end{array}$ & Total & \\
\hline \multicolumn{5}{|c|}{ Tumor stage } \\
\hline 1 & $6(9,8)$ & $31(14,7)$ & $37(13,6)$ & \multirow{9}{*}{0,65} \\
\hline IIA & $28(45,9)$ & $86(40,8)$ & $114(41,9)$ & \\
\hline IIB & 0 & $3(1,4)$ & $3(1,1)$ & \\
\hline IIC & 0 & $1(0,5)$ & $1(0,4)$ & \\
\hline IIIA & $2(3,3)$ & $4(1,9)$ & $6(2,2)$ & \\
\hline IIIB & $14(23)$ & $56(26,5)$ & $70(25,7)$ & \\
\hline IIIC & $4(6,6)$ & $11(5,2)$ & $15(5,5)$ & \\
\hline IVA & $6(9,8)$ & $19(9)$ & $25(9,2)$ & \\
\hline IVB & $1(1,6)$ & 0 & $1(0,4)$ & \\
\hline \multicolumn{5}{|c|}{ Gradus } \\
\hline 1 & $25(41)$ & $77(36,5)$ & $102(37,5)$ & \multirow{3}{*}{$0,17^{\dagger}$} \\
\hline II & $24(39,3)$ & $108(51,2)$ & $132(48,5)$ & \\
\hline III & $12(19,7)$ & $26(12,3)$ & $38(14)$ & \\
\hline Total & $61(100)$ & $211(100)$ & $272(100)$ & \\
\hline
\end{tabular}

${ }^{*}$ Fisher's exact test; ${ }^{\dagger} \chi^{2}$ test

Metastases were found in $27(9,9 \%)$ of patients, and the most frequent localization of the metastases is in liver in 18/26 of patients (Table 4 ).

Regarding the tumor stage, the highest number of patients, $114(41,9 \%)$, had stage IIA, and 70
$(25,7 \%)$ has stage IIIB. According to the tumor grading system, 102 of tumor patients $(37,5 \%)$ had grade I, $132(48,5 \%)$ grade II, and $38(14 \%)$ grade III. There was no significant difference regarding colon cancer localization in terms of grade or stage (Table 5).

Most patients received adjuvant therapy was administered (189 patients; 69,5\%). From the total number of $152(80,4 \%)$ patients, who received chemotherapy only, there are significantly more patients with right colon cancer, while those with left colon cancer received radiotherapy or chemoradiotherapy (Fisher's exact test, $\mathrm{P}<0,001$ ) (Table 6).

Table 6.

PATIENTS ACCORDING TO THE ADJUVANT THERAPY AND COLON CANCER LOCALIZATION

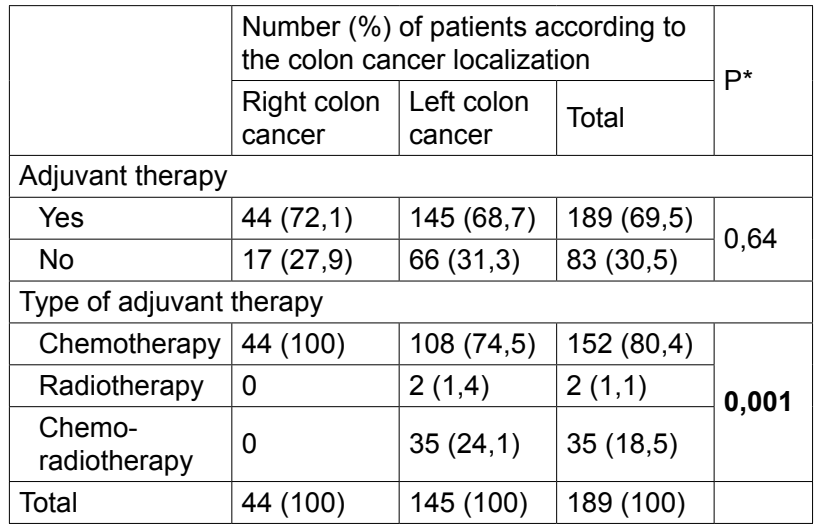

*Fisher's exact test

The time median until the occurrence of metastases is 20 months (interquartile range from 8 to 29 months). The time median is significantly shorter in the right colon cancer group of patients. (Mann - Whitney U test, $\mathrm{P}=0$, 007) (Table 7).

Table 7.

TIME (MONTHS) UNTIL THE APPEARANCE OF METASTASES ACCORDING TO TUMOR COLON LOCALIZATION

\begin{tabular}{|c|c|c|c|c|}
\hline & \multicolumn{3}{|c|}{$\begin{array}{l}\text { Median (interquartil range) according } \\
\text { to the colon tumor localization }\end{array}$} & \multirow{2}{*}{$P^{*}$} \\
\hline & $\begin{array}{l}\text { Right colon } \\
\text { cancer }\end{array}$ & $\begin{array}{l}\text { Left cancer } \\
\text { colon }\end{array}$ & Total & \\
\hline $\begin{array}{l}\text { Time (months) } \\
\text { until the } \\
\text { appearance of } \\
\text { metastases } \\
\end{array}$ & $8(4-23)$ & $20(12-37)$ & $20(8-29)$ & 0,007 \\
\hline
\end{tabular}

*Mann -Whitney U test 
Recurrences or metastases had 88 (32,4 \%) patients, $22(34,9 \%)$ operated patients and 45 $(72,6 \%)$ received chemotherapy (Table 8 .).

Table 8.

THE APPEARANCE OF METASTASES ACCORDING TO TUMOR COLON LOCALIZATION

\begin{tabular}{|c|c|c|c|c|}
\hline & \multicolumn{3}{|c|}{$\begin{array}{l}\text { Number }(\%) \text { of patients according to } \\
\text { the colon cancer localization }\end{array}$} & \multirow{2}{*}{$\mathrm{P}^{*}$} \\
\hline & $\begin{array}{l}\text { Right colon } \\
\text { cancer }\end{array}$ & $\begin{array}{l}\text { Left colon } \\
\text { cancer }\end{array}$ & Total & \\
\hline \multicolumn{5}{|c|}{ Recurrence or metastases } \\
\hline Yes & $21(34,4)$ & $67(31,8)$ & $88(32,4)$ & \multirow{2}{*}{0,76} \\
\hline No & $40(65,6)$ & $144(68,2)$ & $184(67,6)$ & \\
\hline Total & $61(100)$ & $211(100)$ & $272(100)$ & \\
\hline \multicolumn{5}{|c|}{ Surgical treatment of metastases } \\
\hline Yes & $4(33,3)$ & $18(35,3)$ & $22(34,9)$ & \multirow{2}{*}{$>0,99$} \\
\hline $\mathrm{Ne}$ & $8(66,7)$ & $33(64,7)$ & $41(65,1)$ & \\
\hline Total & $12(100)$ & $51(100)$ & $63(100)$ & \\
\hline \multicolumn{5}{|c|}{ Chemotherapy of metastases } \\
\hline Yes & $9(81,8)$ & $36(70,6)$ & $45(72,6)$ & \multirow{2}{*}{0,71} \\
\hline No & $2(18,2)$ & $15(29,4)$ & $17(27,4)$ & \\
\hline Total & $11(100)$ & $51(100)$ & $62(100)$ & \\
\hline
\end{tabular}

*Fisher's exact test

A positive outcome was observed in 205 $(75,4 \%)$ patients, without any significant difference according to the colon cancer localization (Table 9)

Table 9.

PATIENTS REGARDING THE TREATMENT OUTCOME AND CANCER LOCALIZATION

\begin{tabular}{|c|l|l|l|l|}
\hline \multicolumn{2}{|c|}{} & \multicolumn{2}{|l|}{$\begin{array}{l}\text { Number (\%) of patients according to } \\
\text { the colon cancer localization }\end{array}$} & \multirow{2}{*}{ P $^{*}$} \\
\cline { 2 - 4 } & $\begin{array}{l}\text { Right colon } \\
\text { cancer }\end{array}$ & $\begin{array}{l}\text { Left colon } \\
\text { cancer }\end{array}$ & Total & \\
\hline Outcome & $42(68,9)$ & $163(77,3)$ & $205(75,4)$ & \multirow{2}{|l|}{0,18} \\
\hline Survived & $19(31,1)$ & $48(22,7)$ & $67(24,6)$ & \\
\hline Died & $61(100)$ & $211(100)$ & $272(100)$ & \\
\hline Total & & & & \\
\hline
\end{tabular}

*Fisher's exact test

Cancer localization does not show a statistically significant influence on the overall survival rate (Mantel-Coxox, $\mathrm{P}=0,10$ ). Kaplan-Meier survival analysis of the patients divided according to localization shows an overall five-year survival rate of $62 \%$ in patients with right colon cancer compared to $72 \%$ in patients with left colon cancer.

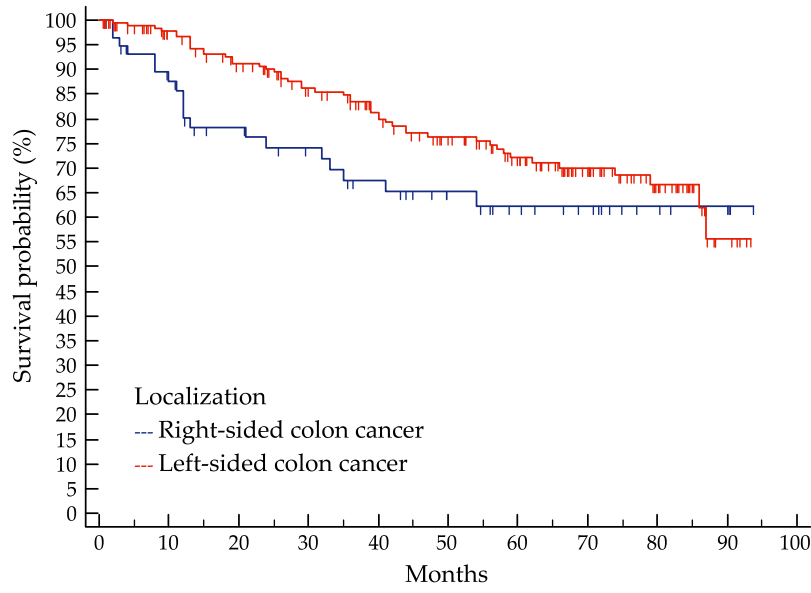

Figure 1. Kaplan-Meier graph - influence of the cancer localizationon the total survival rate

\section{Statistical analysis}

We used MedCalc Statistical Software version 18.2.1 (MedCalc Software, Ostend, Belgium; http:// www.medcalc.org; 2018) for statistical analysis.

\section{DISCUSSION}

This study included 272 patients treated at the Institute for Oncology of the Clinical Medical Centre in Osijek in three years. Of the total number of patients, $42 \%$ were women. Left colon cancer was three times more prevalent than the right colon cancer, which is similar to available registry data (HZJZ). There was no difference in localization when considering patient's gender.

Right sided colon cancer was diagnosed in older patients and was larger at diagnosis compared to left sided colon in this cohort. Mika's study showed that right colon cancer is larger in diameter and that patients who have it are older. That difference in age and size seems related with the difference in clinical manifestations, where right colon cancer is clinically more silent and harder to diagnose than the left colon cancer(31).

On the other hand right sided colon had more lymph nodes harvested during surgery, but without significant difference in tumour involved lymph nodes when compared to leftside colon cancer. However, the involvement of lymph nodes in N1 stage is in favour of the left colon cancer, while in the N2 stage is in favour of the right colon cancer. The lymphovascular invasion did not 
show any significant difference according to the localization of the tumor itself. Moreover, when comparing stages according to TNM classification of tumors, again no difference was found.

As opposed to these results, many studies prove that the right colorectal cancer is more often in an advanced stage, whereas the left colorectal cancer is diagnosed in earlier stages $(3,4,8,9,12)$.

Also, there is a difference in cancer differentiation (gradus). The right colorectal cancer shows a poorer differentiation in comparison to the left colon cancer, $19,7 \%$ to $12,3 \%$. This result corresponds to the Dae Ro Lima's study conducted in South Korea in which more patients $(13,5 \%)$ with right colon cancer show a poor differentiation compared to patients $(4,3 \%)$ with the left colon cancer. The difference could arise from the different embryonal basis of the left and right colon development (31).

Time median to recurrences or metastases was 20 months. We observed a significant difference regarding the left and right colon cancer: the right colon tumors have a shorter time to recurrences or metastases development which is similar to literature data $(3,4,8,9,12,19-2-26,29,31,32)$.

A positive treatment outcome in the survey had 205 patients, which makes 75\%, with no significant difference according to the colorectal cancer localization. Cancer localization does not show a statistically significant influence on the overall survival rate (Mantel - Cox, $\mathrm{p}=0,10$ ).

However, Kaplan - Meier survival analysis of the patients divided according to localization, shows a overall five year survival rate in $62 \%$ of patients with right colon cancer in comparison to $72 \%$ in patients with left colon cancer.

Glebov's study shows that a microsatellite instability is more often in the right colorectal cancer, while a chromosomal instability is charachteristical for left colorectal cancer. Moreover, Glebov and his associates discovered that over 1000 genes have a different expression in right and left colorectal cancer (5). The biology of left and right colon cancer is rather complex, but gradually reveals different surgical and treatment options according to its analysis $(12-18,25,26,31,32)$.

\section{CONCLUSIONS}

1. There is a difference in colorectal cancer behaviour according to the localization itself noticeable in this study.
2. There is a difference in time to metastases or recurrences regarding the localization: this period is much shorter for the right colon cancer than for the left colon cancer.

3. There is a difference in the total five year survival rate according to the cancer localization, and this total five year survival rate is $72 \%$ in patients with left colon cancer in comparison to $62 \%$ in patients with right colon cancer.

4. There is no statistically significant difference in the cancer localization according to the gender.

5. There is no statistically significant difference accoring to the TNM staging.

\section{REFERENCES}

1. Vrdoljak E, Lovasić Belac I, Kusić Z, Gugić D, Juretić A. Klinička onkologija, 3. obnovljeno i dopunjeno izdanje. Medicinska naklada: Zagreb; 2018.

2. Abraham J, Gulley L.J. The Bethesda handbook of clinical oncology. Fifth edition. Philadelphia: Wolters Kluwer; 2019.

3. Sadler $\mathrm{T}$. W. Langmanova medicinska embriologija. Zagreb: Školska knjiga; 2008.

4. Qin Q, Yang L, Sun Y, Ying J, Song Y, Zhang W, Wang J, Zhouc A. Comparison of 627 patients with right-and left-sided colon cancer in China: Differences in clinicopathology, recurrence, and survival. Chronic Dis Transl Med. 2017 Mar 25;3(1):51-59.

5. Glebov O. K, Rodriguez L. M, Nakahara K. Distinguishing right from left colon by the pattern of gene expression. Cancer Epidemiol Biomarkers Prev. 2003; 12:755-762.

6. Krmpotić-Nemanić J, Marušić A. Anatomija čovjeka. 2. izd. Zagreb: Medicinska naklada; 2007.

7. Vrhovac B, Jakšić B, Reiner Ž, Vucelić B. Interna medicina. 4. izd. Zagreb: Naklada Ljevak; 2008.

8. Gervaz P, Bucher P, Morel P. Two colons-two cancers: paradigm shift and clinical implications. J Surg Oncol. 2004;88:261-266.

9. Bauer K. M, Hummon A. B, Buechler S. Right-side and left-side colon cancer follow different pathways to relapse. Mol Carcinog. 2012;51:411-421.

10. Kraljik N., Vajak Ž., Šipoš D. O umrlim osobama u Osječko-baranjskoj županiji u 2016. godini. Dostupno na adresi: http://www. zzjzosijek. hr/uploads/pdf/ publikacije/o_umrlim_osobama_2016_obz. pdf Accessed on 01.05.2018.

11. Šekerija M, Marković T. Epidemiology of colorectal cancer in Croatia and worldwide. Rad 522. Medical Sciences 2015;41:89-95.

12. Baek S. K. Laterality: Right-sided and left-sided colon cancer. Ann Coloproctol. 2017 Dec; 33(6):205-206. 
13. Pappas A.V, Lagoudianakis E.E, Dallianoudis I.G... et al. Differences in colorectal cancer patterns between right and left sided colorectal cancer lesions. J BUON. 2010 Jul-Sep;15(3):509-13.

14. Haggar F. A, Boushey R. P. Colorectal cancer epidemiology: incidence, mortality, survival, and risk factors. Clin Colon Rectal Surg. 2009 Nov;22(4):191-197.

15. Nozoe T, Rikimaru T, Mori E, Okuyama T, Takahashi I. Increase in both CEA and CA19-9 in sera is an independent prognostic indicator in colorectal carcinoma. J Surg Oncol. 2006;94:132-137.

16. Tran B., Kopetz S., Tie J. Impact of BRAF mutation and microsatellite instability on the pattern of metastatic spread and prognosis in metastatic colorectal cancer. Cancer. 2011;117:4623-4632.

17. Goel S, Huang J, Klampfer L. K-Ras, intestinal homeostasis and colon cancer. Curr Clin Pharmacol. 2015; 10:73-81.

18. Hansen IO, Jess P. Possible better long-term survival in left versus right-sided colon cancer - a systematic review. Dan Med J. 2012;59:A4444.

19. Maruta M, Kotake K, Maeda K. Colorectal cancer in Japan. Rozhl Chir. 2007;86:618-21.

20. Benedix F, Meyer F, Kube R, Gastinger I, Lippert H. Right- and left-sided colonic cancer - different tumour entities. Zentralbl Chir. 2010;135:312-7.

21. Bufill JA. Colorectal cancer: evidence for distinct genetic categories based on proximal or distal tumor location. Ann Intern Med. 1990;113:779-88.

22. Nawa T, Kato J, Kawamoto H, et al. Differences between right- and left-sided colon cancer in patient characteristics, cancer morphology and histology. J Gastroenterol Hepatol. 2008;23:418-23.

23. Jess P, Hansen IO, Gamborg M, Jess T, Danish Colorectal Cancer Group. A nationwide Danish cohort study challenging the categorisation into right-sided and left-sided colon cancer. BMJ Open. 2013;3:e002608. doi: 10. 1136/bmjopen-2013-002608.

24. Christodoulidis G, Spyridakis M, Symeonidis D, Kapatou K, Manolakis A, Tepetes K. Clinicopathologi- cal differences between right-and left-sided colonic tumors and impact upon survival. Tech Coloproctol. 2010;14:S45-7.

25. Singh H, Nugent Z, Demers A.A, Bernstein CN. Rate and predictors of early/missed colorectal cancers after colonoscopy in Manitoba: a population-based study. Am J Gastroenterol. 2010;105:2588-96.

27. Meguid R.A, Slidell M.B, Wolfgang C.L, Chang D.C, Ahuja N. Is there a difference in survival between right- versus left-sided colon cancers. Ann Surg Oncol. 2008;15:2388-2394.

28. Bauer K.M., Hummon A.B, Buechler S. Right-side and left-side colon cancer follow different pathways to relapse. Mol Carcinog. 2012;51:411-421.

29. Obrand D.I, Gordon P. H. Continued change in the distribution of colorectal carcinoma. Br J Surg. 1998; 85:246-248.

30. Mik M, Berut M, Dziki L, Trzcinski R, Dziki A. Rightand left-sided colon cancer - clinical and pathological differences of the disease entity in one organ. Arch Med Sci. 2017 Feb 1;13(1):157-162.

31. Lim D.R, Kuk J.K, Kim.T, Shin E.J. Comparison of oncological outcomes of right-sided colon cancer versus left-sided colon cancer after curative resection. Which side is better outcome? Medicine (Baltimore). 2017 Oct;96(42):e8241.

32. Baran B, Mert Ozupek N, Yerli Tetik N, Acar E, Bekcioglu O, Baskin Y. Difference Between Left-Sided and Right-Sided Colorectal Cancer: A Focused Review of Literature. Gastroenterology Res. 2018;11(4):264-273. doi:10.14740/gr1062w

Corresponding author: Darko Kotromanović, Faculty of Medicine, Osijek, Ul. Josipa Huttlera 4, 31000, Osijek, Croatia.e-mail: kotromanovic93@gmail.com 